\title{
Ottoman Empire's Relations with Southern Africa*
}

\author{
AHMET KAVAS \\ DOÇ. DR., İSTANBUL Ü. İLÂHIYAT FAKÜLTESI
}

\begin{abstract}
özet
Osmanlı Devleti'nin Afrika'nın kuzeyinde ve doğusunda yaklaşık dört asır devam eden varlığı akademik anlamda yeteri kadar çalışılmamış bile olsa belli bir bilgi birikimimiz bulunmaktadır. Kıtanın güney bölgesine gelince burasıyla çoğu zaman doğrudan irtibat kurulamadığı için genelde Müslümanların mahalli idarecileriyle veya temsilcileriyle yakın işbirliği kurulması yoluna gidilmekteydi. Kızıldeniz'den sonra Hint Okyanusu'na da açılan Osmanlı donanmasının Piri Reis ile birlikte Hint Kaptanlığı'na dönüşmesi yanında Yemen'in bir eyalet olarak bölgede etkinliği de Güney Afrika ve çevresini doğrudan etkilemekteydi. Afrika'nın bu bölgesindeki Müslümanların Osmanlı halifesine bağ lılığı noktasına odaklanan ilişkiler zaman zaman karşılıklı yardımlaşma imkânlarını beraberinde getirmişti. Zengibar adası merkezli Bûsaîd hanedanıyla işbirliği, özellikle 19. yüzyılda bu bölgede sömürgeciliğin Müslüman topluluklar üzerinde daha az zararla atlatılması için İstanbul'un Avrupa devletler nezdindeki girişimleri gibi konular da yine öne çıkmaktaydı. Özellikle bugünkü Güney Afrika Cumhuriyeti'ndeki Müslüman azınlıklar başta olmak üzere bu ülkenin çevesindeki Mozambik, Demokratik Kongo Cumhuriyeti, Madagaskar, Komor Adaları ve Zengibar Müslümanlarıyla sürdürülen ilişkiler Osmanlı arşiv belgelerine de yansıması bu makalenin muhtevasını oluşturmaktadır.
\end{abstract}

anahtar kelimeler

Osmanlı Devleti, Güney Afrika, Hint Okyanusu, Piri Reis, Yemen, Zengibar

Ottoman's first contact with Africa started after they conquered Egypt in 1517 that had been under Mamluk rule for three centuries. At that time Mamluk defence forces which was fighting against Portugese expansionism around Red Sea and Aden Bay accepted new government in short time.

* Afrika ile ilgili ülkemizde ilk defa 2005 yılında düzenlenen Türk-Afrika kongresinin hazırlık safhasında ve bu makalenin İngilizce tercümesinde yardımlarını esirgemeyen Hasan ÖZTÜRK’e teşekkür ederim. 
These defense forces were very important for the Ottomans for protection of Africa's Eastern coasts. Because if Portugese rule contained Arab peninsula and Red Sea it would be very difficult fort he Ottomans to be dominant power in the region for long time. It is for this reason that the Ottomans felt the need to strengthen the Mamluki defense forces immediately. With the help of this forces that the Ottomans had the opportunity to help Sultanate of Harar in today's Etiopia. By means of this valuable assistance Sultanate of Harar won victories against Christian kingdom that was receiving help from Portugal. This was such a brialliant era that the Sultanate of Harar had its golden age during $16^{\text {th }}$ century due to the presence of Ottoman forces in Red Sea. ${ }^{1}$

This change in Red Sea and Indian Ocean is not well known although it is quite important. Yet, some western historians expressed the importance of this issue in their writings. French historian Jean-Louis Bacqué-Grammont with one of his colleagues wrote an important book only on removal of the Portugese from Red Sea titled: Mamlouks, Ottomans et Portugais en Mer Rouge: l'affaire de Djedda en 1517.

We can also see many historians who paid much importance to this issue. As a result of this development Turks were not confined to only Red Sea but expanded their rule to India and East African coasts.

Yet the Mamluk regime was on its last legs. A new power had risen in the Middle East: the Ottoman Turks. In 1453 they conquered the Byzantine capital of Constantinople, putting an end to the last Christian power in Asia. The Ottoman sultan Selim the Grim took Mamluk Syria in 1516, and the following year decimated the Mamluk cavalry of Egypt-which refused to use firearms-with cannon and arquebuses. The age of the gunpowder empires had dawned.

With victory came mastery of the Red Sea and the trade with the East. The Ottomans inherited the custodianship of the Holy Cities of Makkah and Madinah and the pilgrimage routes. This meant protecting Red Sea shipping from the Portuguese.

«...» In 1538 the Ottomans sent a huge fleet of 100 ships and 20,000 men down the Red Sea. They occupied Aden and captured a number of Portuguese ships. This Ottoman occupation prevented the Portuguese from threatening either Aden or Jiddah any further, and, by the 1560's, more spices, largely conveyed in ships from Aceh, were reaching Jiddah than

1 Cengiz Orhonlu, Osmanlı İmparatorluğu'nun Güney Siyaseti: Habeş Eyaleti, Ankara 1976: Türk Tarih Kurumu, XXVII, 317 p.

2 Jean-Louis Bacqué-Grammont et Anne Kroell, Mamlouks, Ottomans et Portugais en Mer rouge - L'affaire de Djedda en 1517, Le Caire 1988: Institut Français d'Archeologie Orientale, 112 p. 
were reaching Lisbon. By the end of the 16th century, the Portuguese had abandoned any attempt to establish a monopoly of trans-Indian Ocean trade, contenting themselves with their control of the sea route to Europe. Many private Portuguese traders operated on equal terms with their Asian partners and competitors, fully assimilated to the constraints of the Indian Ocean trading network. ${ }^{3}$

Piri Reis who is one of the Ottoman Empire's greatest seamen lived in $16^{\text {th }}$ century wrote a book, Kitâbü Bahriye, and in his book there are very valuable information about West Indian Oceans isles. Provided information in the book ranging from Somali's capital city Mogadishu to Madagascar made the Ottoman Empire know the region in detail while getting knowing Africa and starting relations first time.

One of the more distance cities is known by the name of Sofala. It is rich in gold mines. Another is Mombasa, another Malindi, another Mozambique and stil another Kilva. The most famous however is the city of Mogadishu. There is no city larger than this here. The ships of the Portuguese come to this city every year and take the gold they obtain back to their country. ${ }^{4}$

Now I have told you one by one everthing there is concering the country of Mogadishu, which is called Abyssinia. See now the islands good friend, and hear what is located on them. There exists an island there known by the name Zanzibar. It is inhabited by the Muslims. ${ }^{5}$

«...» There is a great island there that they call Tinku. The Franks call this island San Loranzo (Madagascar) while the Arabs call it Kûmûr. «...» The language they speak in the language of Mogadishu and they call this place Tinku. «...» The most valuable product there is the wood of the sandal tree. In that country this is all that they burn. Another things teh respect is a their balck rulers whom they obey like sultans. Their ruler at one time was Sultan Adil bin Muhammed Han. There are large cities there and all the inhabitants are black. One of the cities Re's-i Bîmâr (Vohimarina - Port in the eastern coast of Madagascar) and another they call Sa'de (Port on the west of Madagascar). One of the cities is Lankaniki (capital of Madagascar, located on western coast), their capital. All the people here are of the Shafii sect. Good friend, there are also tribes dwelling far from the sea that are all savage blacks. They now neither religion nor custom and heed no man's word. The people of the cities go island; and capturing them, they bring them down to the ships where they sell them. In this way they go on continuous slave hunts day and night. ${ }^{6}$

Besides this island there are four more, and all together they are called the Comoros Islands. Each one these islands has a separate name. Tell me each one. One of these islands they call in fact Mu'alî (Moheli). This island

3 Paul Lunde, "The Coming of the Portuguese", Saudi Aramco World, (24 August 2006).

4 Pîrî Reis, Kitâb-ı Bahriye, (nşr.: Ertuğrul Zekâi Ökte ve dğr.), İstanbul 1988, I, 167.

5 Pîrî Reis, Kitâb-ı Bahriye, (nşr.: Ertuğrul Zekâi Ökte ve dğr.), İstanbul 1988, I, 171.

6 Pîrî Reis, Kitâb-ı Bahriye, (ed. Ertuğrul Zekâi Ökte ve others.), İstanbul 1988, I, 173-77. 
has three large cities. Its inhabitants are all of the Shafii sect and all perform their ablution. Because the shah of shahs rules not this island, it is governed by council of elders.

The second island they call Mâgûtâ (Mayotte). The Portuguese occupied this place and wished to establish a colony here. «...»I will tell you that the isand has a ruler who loves God greatly. He is Muhammed b. Omar, the son of a sultan, and he is the sovereign of the island. Some of the population are black and some are white. They are of the Shafii sect and there no divisions among them. Hear nom about the city they call Shinkûnî ("i" Principal city of Mayotte island) and what is said concerning it. There was a famous saintly man there who throughout the months lamented to God day and night. Tehy called him Fakî Molâzî and no one tired of conversing with him. One day when this monk was performing his devotions, the Portuguese came up suddenly upon the island. The Portuguese drew near and dropping anchor before the city declared their intention to fight. The whole populace of the city as a group collected before the door of that monk's cell. Tehy each told him that the Portuguese had come, explaning the situation and saying to him "O imam, help us. The Portuguese have come and wish to the battle here". That holy Saint prayed day and nigth. The weather suddenly rose up, teh wind blowing fiercely. The Portuguese had with them fully fifteen ships. That nihth there were heavy gales. And that night all the ships' hawsers borke and each and every man perished then and there. It is fort his reason that whenever the Portuguese come this way, they never drop anchor here. For their souls burned there and so they give this island wide berth.

Hear now about the third. This is the third of the islands and its name is Züvânî (Anjouan, third of the Comoros Islands). All the inhabitants of this island are black. A sheik rules over them and them and they have no other sovereign. All of them arae Muslims of the Shafii sect and they are all champions of the Faith.

Now if you wish let me tell you the situation of the fourth. Behold the circumstances of this island: it is loftier than the others. Thougth it has high mountian it lacks streams and there is no good harbor her efor ships. They call it Kazîja (Grande Comore [Ngazidja]) and it is ruled over by forty great sheiks. They hunt each other down and sell their prey. They are good hunters like Tartars.

Good friend I have explaned thes five islands and now you should see what sort of customs they have. They treat their slaves like sheep and lambs. Some are old and some are young. There are men with a thousand slaves male and female. These are cared for like cattle. And their sons and daughters they constanly put up for sale. Sailors come hither and buy them. They fill their ships and take them away. Tehy always sell them in Yemen thougt sometimes they take them as far as Jedda. I have told of the particulars of this island. Now hear about the others.

Besides this islands there are two more which are also among the Comoros islands. On of these is Penba, the other is Zanzibar. Both tese islands are large ones. This island that I have called Penba is also known as 
Akhdar. This island has so many vineyards and gardens that were a man to enter here he would become lost. ${ }^{7}$

In order to be powerful in Indian Ocean it was necessary to possess Yemen. The Ottoman Empire expanded her borders to the furthest point in her entire history during the time of Sultan Murad III (1574-1595). The Sultan personally appointed Hasan Pasha, one of the people whom he trusts much, as the governor for the region just to show how the region is important for him (1580-1604). Return of this governor back to Istanbul was after 24 years. Sultan that appointed him to Yemen passed away but due to his achievements he was ordered to remain there although he demanded return to Istanbul several times. Because he was ruling this land assigned to his will perfectly. ${ }^{8}$ On the way of India the Portugese tormented rulers of Southern Arabia and the Coastal region ranging from Somali to South Africa. Hasan Pahsa heard the cries of these people and while he sent troops to Oman coasts he also sent the fleet to Mombasa twice and saved the region from Portugese invasion. In all these expeditions his best supporters and assistants were local people and their rulers who declared their declared to Hasan Pahsa.

It was not till the year 1580, in the time of Sulayman's grandson, Murad III,
that a renewal of the struggle took place. It was however, local, being
entirely confined to the coast of East Africa. «...» The attack on the Portuguese
seems to have been the work of one man, Ali Beg, who was sent out by the
Albanian Wali of Yemen. It is doubtful whether ordered or inspired from
Constantinople, and it does not seem to have been mentioned by any
Turkish historians. «...» Teh Arabs who had declared in favour of the Turks
continued to defy the Portuguese, and in 1589 the Wali sent out Ali Beg a
second time with a beter equipped expedition, consisting of four galleys
and the ship captured in the first attempt. Had the Turkish rulers now
been in a position to send out a strong fleet they might possibly have
overthrown the Portuguese naval power. «...» Ali Beg received with entu-
siam by all the Arabs who had declared for Turkey, but, as before, Malindi
defied him. Ali Beg grounded on a sandbank and was bombarded by the
Portuguese. He got away to Mombasa, intending to fortify himself there.
«...» The fleet (Portuguese) arrived on the coast of Brava, and following it
to the South by the Lamu Archipelago received news taht the Turks were
at Malindi. He foud on arriving there that they had gone to Mombasa. The
fleet arrived at the entry of the port on March 5 , 1589. The fight which
followed ended in the destruction of the Turkish fleet and the capture of
the fort which they occupied. Many Turks who took refuge on the main-

7 Pîrî Reis, Kitâb-ı Bahriye, (nşr.: Ertuğrul Zekâi Ökte ve dğr.), İstanbul 1988, I, 179-187.

8 Hulûsi Yavuz, "Hasan Paşa, Yemenli", TDV-İslam Ansiklopedisi, XVI, 341-342. 
land were killed and devoured by a cannibal Bantu tribe, known to the Portuguese as the Zimbas, who had for some years been spreading desolation along the African coast from the Zambezi northwards. This completed the Turkish discomfiture. Ali Beg himself surrendered. He was taken to Lisbon. ${ }^{9}$

Existence of Bûsaîd Kingdom strengthing from Oman to Zanzibar in Indian Ocean had been a way of salvation fort he Muslims of the region. Ottoman Empire improved relations with this Kingdom especially in the second half of the 19th century. ${ }^{10}$ Sultan of Zanzibar Seyyid Ali Bin Hamud (1902-1911) came to İstanbul and had talked to Sultan Abdulhamid II. He was welcomed in Istanbul at utmost level and he was given accompaniments.

Sayyid Ali loved to travel and he spent a good deal of his time aboard. Being in delicate state of health, he also had to receive treatment in Switzerland and Germany from time to time. While returning home, November 1907, he paid a short visit to Turkey, where he was received with considerable honour. ${ }^{11}$

Seyyid Ali's visit to İstanbul had a major impact in that day's papers. Particularly İkdam Gazetesi published news about the visit on Novemer 2, 1907:

Pour témoigner de son attachement sincère à sa Puissance Majesté l'Ombre d'Allah, Sa Glorieuse Altesse l'Emir de Zanzibar, arrive hier à İstanbul, est venue dans la soirée, avec son escorte, au Palais. Elle a accompagné à la mosquée Sa Sublime Majesté, refuge du Khalifat, pour y célébrer la nuit de la prédestination (Leileteu'l-kadr), et, après avoir fait la prière, s'est rencontrée au Palais impérial avec Sa Puissante Majesté Porte Couronne. En outre, elle a été invitée, pour demain soir, par Sa Majesté Impériale, à la fête de la rupture du jeûne. ${ }^{12}$

It is also known that Istanbul stayed in touch with Sultan Bergas, one the Sultans of Zanzibar and told him about Istanbul's support.

Today one of the historical events that is known both in Turkey and South Africa is the appointment of Ebubekir Efendi by the Sultan from

9 M. Longworth Dames, "The Portuguese and Turks in the Indian Ocean in the Sixteenth Century", Journal of The Royal Asiatic Society (JRAS), 1921, 1-28.

10 Hatice Babavatan, Understanding 'Afrikâ-yi Osmânî' in the Late Ottoman Period: The Case of Zanzibar, Master of Arts in History, Boğaziçi University, 2003 and Osmanlı Afrikası'nda bir sultanlık: Zengibar, İstanbul 2005: Küre yayınları, X, 113 p.

11 Ahmed Hamoud Al-Maamiry, Omani Sultans in Zanzibar (1832-1964), New Delhi 1988, p.5658

12 L. B., "L’Emir de Zanzibar à İstanbul”, Revue du Monde Musulman,III, 1907, p.518. 
İstanbul for the Muslims of South Africa on exclusive mission. Achievements of Ebubekir Efendi were not confined to South Africa. The Ottoman Empire even planned to find scholars like him and to send them to Europe. But it was really difficult to find scholars who has the same enthusiasm he had. Even while he was alive people knew his achievements but plans of finding another person like him was not realized. European colonialist states were afraid of Ottoman Empire's appointments of scholars like Ebubekir Efendi to various parts of Africa. Diplomatic missions of some special ambassadors such as Sadik el-Mueyyed Pasha who was sent to Etiopia and Libya by Sultan Abdulhamid II, had been followed closely by the European embassies in those countries. Sadık el-Müeyyed Pasha like Ebubekir Efendi was not satisfied with going for diplomatic missions but he also wrote what he observed and experienced and compiled these as a book.

After sending Ebubekir Efendi to South Africa Ottoman Empire henceforth started to be interested in Muslims there more closely. A consul was appointed. They decided to open a school especially for educating Muslims there. The school was named as Osmanlı Mektebi. Even appointment of teachers for this school has been planned. This school dres Muslims in South Africa nearer to Ottoman Empire.

A newspaper called The Cape Argus made a comprehensive news about the school in South Africa opened by Ottoman Empire. As can be understood from this news Ottoman Empire was interested in Muslims in very South part of Africa:

Hadje Emaum Magnoel Efendi, Professor of the Otoman Arabic School in the Peninsula, has conveyed his loyal and dutiful sentiments to his Highness Muhmmed V., and a prayer for the new ruler has been given out for the Musselamn community in the Peninsula.

Over 70 years ago, Hadje Effendi's father was a member of the first Cape pilgrimage to Mecca, and it was in his return from the pilgrimage that for the first time a prayer for the Otoman ruler was included in the service of the Peninsula Muslims. On receipt of a letter from Mecca officially announcing the elevation to the throne of his Higness Reshad Efendi as Sultan, the prayer for the new ruler was announced. It is the profound hope of the Muslims in the Cape that the new Sultan will not forget them, that he will continue the modest benefices from the Imperial Treasury for the widows and for the schooling of the orphan children of Muslem parents. Hadje Emaum Efendi was appointed by the Otoman Government as teacher of the Otoman School in Cape Town at a salary of ten Turkish pounds per month in 1894, Mr. H.L. Myburg, as Otoman Consul General, endorsing teh appointement, and he has carried out his duties as teacher with mar- 
ked success. As Emaum he has officiated at the Moslem New Year, and the Sultan has in him a very faithful and officient servant. ${ }^{13}$

Piri Reis provides a lot of valuable information about Comoros Islands in his book called Kitâb-1 Bahriye. But unfortunately Ottoman intelligentsia didn't follow the path he opened as it deserves. There had been some times that even the top level state bureaucrats became ignorant of information he provided. Comoros Islands wanted to inform Istanbul when the French started to colonize their land in 1840s. Sultan of Anjouan whose island was not colonized by the French caused the local people suffer and tormented too much in cooperation with the British consul. Those of local people who wanted to inform Istanbul of what was going on first send two of their princes to London to complain the consul. Ottoman ambassador in London welcomed them, paid much attention, paid for all of their expenses in London and informed Istanbul of their visit. They were welcomed perfectly when they got İstanbul and they were paid salaries as long as they stayed in the Sultan's palace. The thing that surprised two princes was that many of the Ottoman authorities were not aware of their countries. In short this shows us that the information Piri Reis provided 300 years ago has just been left aside. ${ }^{14}$

In this era Suez canal was not opened and Ottoman Empire kept contact with its fleets in Basra Gulf by going around Cape Town. Ottomans decided to transfer two princes with the first ship. It was the duty of commander of the ship that when they arrive in Comoros Islands he was supposed to convey a letter containing some advice to ben handed to the Sultan of Anjouan and he had to warn him orally not to torment his people.

Dependence and devotion of Egypt, North Africa and East Africa can be known. But devotion of Muslims who lived in Southern Africa to Ottoman Sultan is worth appreciation. They were so devoted and felt affiliated that even the workers in diamond mines sent greetings every year for the ceremonies on anniversary of start of Sultan Abdulhamid II's ruling period:

Kimberley, South African Diamond Fields. April 1890. To His Imperial Majesty Sultan ul Ghazi Abdul hamid Khan II, Ruler of The Imperial Otoman Empire, commender of the Faithful Ghadimoul harmanie Sharifain. We the undersigned Aemma, Khotabah and Muezzens, representing the Colonial and Indian Mahomedans of the South African Diamond Fields, humbly desire with all reverence and affection to Express to Your Impe-

13 Archives Ottomanes - Istanbul, I.Hus.: 212/44, date: 27.1.1327. (The Cape Argus, Monday, June /, 1909 -The Moslem Schools).

14 Archives Ottomanes - İstanbul, DUIT, yıl.1281-Meclis-i Mahsus, n. 1254; HR. SYS., 8.4.1905, n. $431 / 1$. 
rial Majesty on the occasion of your entry upon your fiftienth year our heartfelt wisnes for your long life and happiness.

It is with the deepest gratitude we remember that, although separated from Your Imperial Majesty by thousands of miles, we have yet been pernmitted to participate in the beneficence of your sway, and that Your Imperial Majesty has at all times evinced the kindliest interest in our social, moral and spiritual welfare.

We on our part have watched with ever increasing pride the marked advancement which, under Divine Providence, the Otoman nation has made during the fourteen years of your wise and just rule, and we pray taht Your Imperial Majesty may long be spared to reign over a loyal loving and prosperons people.

To Your Imperial Majesty's person the Mahomedans of the South African Diamond Fields are bound by all the ties of religion and affection. We are indebted to Your Imperial Majesty for the incalculable advantages of the Imperial Otoman Free School, and are gratified to know that the spread of education among our. Musulman youth will un the coming years add to the undying glory of Your Imperial Majesty name.

We humbly pray that all earthly blessings may be showered upon Your Imperial Majesty, that Your Imperial Majesty may enjoy all the happiness that attends a precious life devoted to the noblest aims, and that Your Imperial Majesty may long be shared to shed increased lustre upon a reign already made glorious in the annals of the far reaching Otoman Empire. We are Your Imperial Majesty's most humble and loving servants. ${ }^{15}$

Ottoman Empire constructed railway between Istanbul and most sacred two cities Mecca and Medina. They expressed their support to all Muslims with this enterprise. Even Muslims of Mozambique's capital city Loranso Marquiz sent the donations among themselves to Istanbul. Ottoman Empire gratified and rewarded each one of these people with a medal. ${ }^{16}$

Muslims living in Island of Indian Ocenas from Mauritius and Madagascar contacted newly formed Turkish government in Ankara in the last days of Ottoman Empire. So the help was mutual not unilateral, Ottoman Empire helped African in the past and Africans also helped Ottomans. Muslims from Mauritius helped Ottomans after the war between Ottomans and Russians in 1877. Moreover, in 1920s they collected some amount of money among themselves and sent to Ankara government after the national independence struggle was won. During the first campaigns for collecting aid a person who was in the position of head of Muslims had had written all the aid to the Ottoman consul. He also wanted to salute his people on national days in Ottoman clothes and demanded from Istanbul

15 Archives Ottomanes - Istanbul, Y.PRK.MF., 2/8.

16 Archives Ottomanes - Istanbul, Y.MTV., 280/40. 
to send necessary things. All the things he demanded were sent to him immediately. In the documents about the people of these islands we can see the pictures of elite of the society wearing Ottoman clothes on important occasions. Head of the Muslims in Mauritius wrote a letter personally to Sultan Abdulhamid II and expressed their situation:

A Sa Majesté Abdoul Hamid, Sultan de la Sublime Porte. A l'honneur de nous exposer très respectivement, le soussigné, Sheik Nasirouddine, fils de Gassy, Grand Prêtre Mahométan, résidant à l'Ile Maurice.

Lue votre pétitionnaire a été nommée, à la place du Grand Prêtre en cette Ile Maurice, par toute la communauté Musulmane, en dâte du 24 Mars 1859, que sa nomination a été sanctionnée par votre prédécesseur, Sa Majesté le Sultan Abdool Aziz, dans la même année et inscrite au Régistre du Consulat de la Sublime Porte, le 29 Août 1865.

Lue votre pétitionnaire, prend la liberté de venir vous soumettre très respectueusement, qu'il est obligatoire à tous ceux qui doivent faire partie des réunions officielles qui se tiennent à l'Hôtel du Gouvernment; notamment au "Lever" de Sa majesté la Reine d'Angleterre, se présenter en Uniforme comme il est dit dans l'avis du Gouvernement inséré dans la Gazete-ci-jointe.

Lue votre pétitionnaire, n'a pas le costume, que doivent porter ceux de son titre et de son rang, il vient conséquemment supplier votre Majesté de vouloir bien ordonner, qu'il lui en soit doné un, enfin qu'il s'enserve, le jour des Réunions Officielles, il vous en sera très reconnaissant et il ne manquera pas de prier Dieu, pour la prolongation de vos jours. Nasirouddine Gassy Sobdar. Port Louis, le 9 Juin 1879. ${ }^{17}$

Muslims of Mauritius and Madagascar exerted much effort to send the aid they collected to Ankara. They started campaigns for collecting aid for Turks waging war against Europeans and sent the collected aid to a magazine, Echos de l'Orient, published in Paris. The magazine announced to its readers the name of people who donated and what is donated:

Un de nos amis de Tamatave, M. Ibrahim Mansour, a eu l'amabilité d enous adresser un chèque de 18.593 Fr. 55 centimes pour transmettre à S.E. Moustafa Kemal pacha, à Angora, au profit des oeuvres de secours turques. Cette somme est le produit de collectes faites à Madagascar et de donations de nos coreligionnaires en réponse ou généroux apel de M. Ibrahim Mansour, à qui nous sommes heureux d'adresser ici nos chalereux remerciments ainsi qu'à tous les donateurs.

Nous espérant que nos amis de Madagascar voudront bien nous continuer leur généreux appui en raison des nombreuses difficultés qu'il nous faut surmonter pour l'accomplissement de Notre tâche. ${ }^{18}$

17 Archives Ottomanes - Istanbul, Y.PRK.TKM.,3/4.

18 "Un don libéral des musulmans de madagascar aux oeuvres de secours turques", Echos de l'Orient (Anciens Echos de l'Islam), 3è année, n.:55, 1 Agutos 1922. 